れるものと期待される.この分野における研究が継続的に 進展してゆくことを望みたい.

これらに加え, カーボンナノコイルを添加した樹脂系の 電磁波特性を取り扱ったもの，および光ファイバー作製時 に，屈折率制御のために添加する低分子量化合物の拡散挙 動をその構造と関連させて考察したものなど，従来この セッションではあまり見られなかった領域の研究も散見さ れるようになってきた。
なお本セッションのうち約半数の 9 件が産学あるいは産 官などの連名による報告であった．研究の深化に伴い，各 機関の得意分野を持ち寄った連携がますます進んでゆくも のと思われる．紙数の関係ですべての報告を取り上げるこ とはできないが，いずれも有益な知見を有しており議論も おおむね活発であった. 本セッションのさらなる発展に期 待したい.

\title{
一般セッション
}

\section{CAE $(\mathrm{E}-101 \sim \mathrm{E}-104)$}

瀬 戸 雅 宏*

近年, 研究開発や製品開発における効率化, コスト削減 はますます需要性を増しており，CAE 技術の確立，有効 活用が強く望まれている. 本セッションは大会初日の午前 中のセッションであったが, 多くの聴講者が出席されてお り，CAE 技術の重要性，期待が伺うことができた。

射出成形品のそり変形発生要因としては, 樹脂流動に よって分子が配向し，線膨張係数などの物性值に分布や異 方性が生じることによってそり変形が発生する流動要因と, 射出成形中の成形品や金型の温度分布, 冷却速度差によっ て収縮差が生じ，そり変形が発生する熱要因が知られてい る. 瀬戸らは, 流動要因に着目して, 樹脂のせん断流動に よって生ずる成形品板厚方向の物性值分布を予測するため, 射出成形中の板厚方向の樹脂流速分布および固化層成長挙 動に与える成形条件の影響について検討し, 樹脂温度や金 型温度のみならず，保圧力によっても固化層成長速度が変 化することを報告した $(\mathrm{E}-101)$. 一方, 今嶋らは 3 次元 非定常金型温度解析を実施して, 従来のサイクル平均理論 による金型温度解析よりも高精度でキャビティ表面温度お よび成形品表面温度をシミュレートし，そり解析精度が向

\footnotetext{
* Seto, Masahiro

金沢工業大学 ものづくり研究所

白山市八束穂 3-1（９ 924-0838）
}

上することを確認している $(\mathrm{E}-104)$. 今後これらの研究 成果を融合することによって，そり解析のさらなる精度向 上が期待される.

また， $2.5 \mathrm{D}$ および $3 \mathrm{D}$ にて肉厚分布を持った射出成形 平板をモデル化し，種々の要素タイプ，材料モデルで射出 成形中のフローフロント進展や樹脂圧力の解析精度を検証 した報告もあった．形状にもよるだろうが，流動解析にお

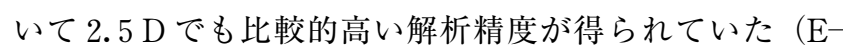
103). 解析精度の向上には, 成形現象の解明やモデルの高 精度化のみならず, この研究のように要素タイプや材料モ デルの影響についても議論が必要であると考えられる.

鮎澤らは，PTFEテープの延伸による多孔質化をシミュ レートする解析モデルを構築し, その妥当性を検討した $(\mathrm{E}$ -102). 通常のフィルム延伸シミュレーションでは, 緻密 体を前提とした連続体力学に基づいて計算されるが，本研 究は独自の考え方でモデルを構築しており, 適用範囲はあ るものの実験結果と良く一致していた.

CAEの高精度化に加えて, CAEを“使いこなす”こと によって，新たな分野への CAEの活用が広がり, CAE がプラスチック成形加工における高付加価值化や技術発展 に大きく寄与することを期待する.

\section{学生ポスターセッション}

\section{学生ポスターセッション報告}

今年度のポスターセッションは, 学生および一般ポス ターセッションの 2 つにかれて実施され, 学生ポスター セッションは大会初日の昼休みに $1 \mathrm{~F}$ 展示ホールにて, 42 件の発表が行われた。昨年度は在学中の学生だけでなく， 入社後 3 年までの若手研究者・技術者を対象としたヤング ポスターセッションとして実施されたが, 今年度は在学中 の学生だけに限定して実施された。これは, 馬場実行委員

\footnotetext{
* Nishitani, Yosuke

工学院大学 工学部 機械工学科

八王子市中野町 2665-1（兵192-0015）
}

西 谷 要 介*

長をはじめとした関係者が共有している「プラスチック成 形加工に関わる次世代の優秀な人材育成・発掘」の最適な 場となることを期待したためである，そのため，例年以上 に会場は熱気にあふれ，活発で積極的な議論が各所で見受 けられたことは，大変喜ばしいことである.

本セッションの趣旨を反映し, 学生らしい元気な発表の うち, 特に優秀な発表について, 学生優秀ポスター賞とし て，企業・大学・公的機関の若手（?）審査員の方々を中 心に審査して頂いた。審査の結果，学生優秀ポスター賞に は以下の 5 件が選ばれた。 
- 中安康善 (同志社大学) :「ポリマー/クレーナノコンポ ジット製造プロセスの研究」(SP 08)

- 大江祥元 (東京農工大学) : 「超臨界二酸化炭素処理によ る高分子電解質のイオン電導挙動とイオン解離状態の解 析」(SP 15)

・鳥羽高志 (工学院大学) :「UHMWPE 充填ポリアミド 12 系 TPE 複合材料のトライボロジー的性質」(SP 18)

・宮川紘一 (東京工業大学) :「炭酸ガスレーザー照射によ る樹脂材料表面の局所炭化と導電性の発現」(SP 40)

・安部哲生 (山形大学) : 「ヒートシール時のフィルム接着 過程に及ぼす結晶化の影響」(SP 42)
学生優秀ポスター賞の表彰式は懇親会の席で行われ，馬 場実行委員長より各受賞者に記念盾が贈られた。この学生 ポスターセッションが関係者各位に広く認知され，次世代 の人材育成・発掘の場として広まることを期待していきた い. 残念ながら, 本年度発表を行った教育機関は 10 大学 と限定されたものであり，今後は全国の幅広い教育機関か らの発表が増えること, さらには成形加工分野の登竜門的 な場として活用されることを期待している.

最後に紙面をお借りして，本セッションを行うにあたり ご協力頂きました審査員をはじめとした関係者, ならびに 貴重な議論をして頂いた聴講者の皆様に深く感謝致します.

\section{一般ポスターセッション}

\section{ポスタープレゼンテーション賞報告}

山田岳 大*

大会 2 日目に行われた一般ポスターセッションは，昨年 同様に, 前日に行われる学生ポスターと平行して行われた. 一件のキャンセルがあったものの発表件数は 37 件となり， 「家電・情報機器を支える成形加工」, 「アロイブレンド」, $\lceil$ 押出成形」, 「構造・物性・評価」, 京都の伝統工芸等, 多 岐に渡る内容であった. ポスターに関しても思考を凝らし たポスターが見受けられ，華やかな会場となった。また， プログラムがタイトであったが発表序盤から多くの人が集 まり始め, 活発なデイスカッションが行われた。会場は, 通年どおり機器展示と企画展示と共有する形で行われたも のの, 比較的ゆとりのあるスペースでディスカッションが 出来たものと思われる.

希望者を対象としたポスタープレゼンテーション賞が審 査員により 2 件選出された.

以下に選出された題目と発表者を記す.

「コア回転・配向制御射出成形技術を使った射出成形品の 性能向上」

中村 太一氏 (スターライト工業(株)

\footnotetext{
* Yamada, Takehiro

埼玉県産業技術総合センター 生産技術担当

川口市上青木 3-12-18（テ333-0844）
}

「単軸押出機の混練特性の評価」

木村 公一氏 (株日本製鋼所)

表彰式は B 会場 $2 \mathrm{~F}$ (平安) で行われ, 馬場実行委員長 より各受賞者へ記念盾が贈られた。

受賞された方々からいただいたコメントを記す。 中村 太一様 (スターライト工業(株) より

「この度は名誉な賞を頂き，ありがとうございました。 これを励みとし，更なる技術開発を進め，世の中の 価值向上の一助となれればと思います。」

\section{木村 公一様（株）日本製鋼所）より}

「この度, 大変名誉ある賞を頂き, 誠にありがとうござ いました.この受賞を励みとし, 今後も研究開発に邁進し ていく所存です. 本研究の遂行にあたってご指導を賜った 方々にこの場をお借りして御礼申し上げます。」

次回も多くの研究員の応募発表を望み, 今後の研究進展, 研究活動のつながりの場として, ポスターセッションがよ り活発化することを期待する. 最後に本セッションを遂行 するに当たり，お忙しい中審査にご協力いただいた多くの 関係者の方々に本紙面をお借りしまして感謝を表します. 